\title{
The Relationship Between Farmers' Quality of Life and Their Leadership Competencies
}

\author{
S. Windon ${ }^{1}$, D. Robotham ${ }^{2}$
}

\section{Abstract}

This quantitative study sought to explore Pennsylvania farmers' perceptions of their quality of life during their busiest farm season and its relationship with farmers' self-leadership and ability to lead others' competencies. The convenience, unrestricted, self-selecting, and chain-referral sampling approaches were used to collect online data. The final data set included responses from 59 farmers. The overall mean score for self-leadership competencies was $3.93(S D=.48)$, ability to lead others' competencies was $3.96(S D=.50)$, and farmers' quality of life was $3.49(S D=.69)$. A significant positive association found between farmers' quality of life and self-leadership competencies $(r=.64$ $p=.001)$, and ability to lead others' competencies $(r=.24 p=.013)$. Approximately $43 \%$ of the variance in overall farmers' quality of life was explained by farmers' self-leadership and ability to lead others' competencies. Extension practitioners should develop a leadership program for farmers that will address the following areas: farmers' work-life balance during busy season and difficult conversations with farm employees.

\section{Keywords}

Farmers' quality of life, farmers' self-leadership competencies, farmers' ability to lead others competencies

1. Suzanna Windon, Assistant Professor on Youth and Adult Leadership, Department of Agricultural Economics, Sociology, and Education, The Pennsylvania State University, 209 B Ferguson Bldg., University Park, PA 16802, sxk75@psu.edu,

(iD) https://orcid.org/0000-0002-9103-5123

2. Daniel Robotham, M.S. Student, Department of Agricultural Economics, Sociology, and Education, The Pennsylvania State University, 112 Ferguson Bldg., University Park, PA 16802, djr6131@psu.edu, 


\section{Introduction and Problem Statement}

Nitsch (1987) described farmers' lifestyles as autonomy, closeness to nature, tradition, and continuity. However, despite the idyllic lifestyle associated with farming, the landscape of farming is changing, with the number of farms in Pennsylvania consistently declining since 2007 (United States Department of Agriculture National Agricultural Statistics Service Information [USDA NASS], 2017). The consolidation of agriculture in the United States over the past 40 years has resulted in fewer, larger farms and has fundamentally changed the responsibilities of farmers (MacDonald, 2020). Farmers today must have the ability to manage large groups of employees, navigate complex production and distribution markets, and deal with constant pressure to innovate and adapt to new technology (Ulvenblad \& Björklund, 2018). According to leadership literature, leadership is the ability to share a vision with others and identify goals to which others also aspire, thus increasing productivity, efficiency, and impact (Hughes, 2007).

The increased responsibility and pressure in the agricultural sector have had significant consequences for farmers' quality of life. Farmers' work environmental characteristics are associated with a relationship between farmers' quality of life and quality of work (Clark, 2010). Kong et al. (2019) mentioned that farmers' optimization of their organizational management and improvement of their interpersonal relationships that influence their quality of life might also be important factors toward their motivation to work. Hughes (2007) emphasized that leadership functions at different levels and in different capacities within an organization. In the literature, leadership term is conflated with management and administration. However, in the practical world, the three often function together.

According to the literature, leadership is associated with strategic decision-making, whereas management assures the organizational capacity to reach goals and the human and physical resources are sufficient. Administration ensures effective day-to-day operations are efficient. Moreover, administration includes the responsibility for the working environment, financial records, personnel issues, and activities necessary to keep an organization running efficiently (Fullan, 2001; Nanus, 1992). Hughes (2007) indicated that organizational leaders should be able to distance themselves from the daily managerial and administrative routine and devote their time to their leadership role.

There were limited studies found that discuss the relationships between farmers' quality of life and farmers' self-leadership and ability to lead others' competencies. Hence, this exploratory study investigates Pennsylvania farmers' perceptions of their quality of life and analyzes its relationships with farmers' self-leadership and ability to lead others' competencies.

\section{Theoretical and Conceptual Framework}

The study on which this research is based utilized the American quality of life framework, which focuses on subjective quality of life or well-being of individuals (Campbell et al. 1976) and the leader and leadership development theoretical framework (Day, 2000). Quality of life is a broad 
term referring to a person's view of their current life standing. This is influenced by several factors, including physical health, self-esteem, expectations, and values (World Health Organization, 1997). There are generally two global frameworks used in quality-of-life research: American and Scandinavian. The American quality of life approach largely focuses on the subjective quality of life or well-being of individuals (Campbell et al., 1976). Scandinavian studies focus on the objective living conditions of individuals or societal quality of life (Noll, 2002). In this study, we utilized the American framework that described subjective well-being as individuals' perceptions of their life and work (Coughenour \& Swanson, 1988). Providing reliable and valid quality of life indicators is a solid approach for policymakers who plan factbased courses of action (Young, 2008). The subjective well-being approach is based on human needs, expectations, phenomenological viewpoints, preference satisfaction, hedonism, and life satisfaction (Karimi \& Brazier, 2016). Examples of definitions of quality of life are: "a conscious cognitive judgment of satisfaction with one's life" (Rejeski \& Mihalko, 2001, p. 23) and "an individual's perception of their position in life in the context of the culture and value systems in which they live and in relation to their goals, expectations, standards, and concerns" (Whoqol Group, 1995, p. 1405).

Bogue and Phelan (2005) stated that farms are complex. Molnar (1985) emphasized quality of life as a global construct based on an individual's expectations and life experience (Windon et al., 2016). Satisfaction with farm work influences satisfaction with farm life (Coughenour \& Swanson, 1988). The interpretation of farm family quality of life can be a challenge for researchers as farm families measure the quality of life on many levels. Because of farmers' ever-changing life, work conditions, and current life experience, quality of life studies are typically exploratory (Windon et al., 2016).

In this study, we utilized Day's (2000) leader and leadership development theoretical framework, which distinguishes leader development and leadership development based on intrapersonal and interpersonal competencies. Harder and Narine (2019) defined competencies as a set of "knowledge, skills, and abilities commonly associated with professions" (p. 224). McClelland (1973) emphasized the importance of using competencies in professional development because it determines employee success (Harder \& Narine, 2019). Day (2000) described leader development as developing intrapersonal or self-leadership skills that are characterized through competencies such as self-awareness (self-confidence, emotional awareness, accurate self-image), self-regulation (personal responsibility, trustworthiness, selfcontrol), and self-motivation (initiative, commitment, optimism). Day (2000) characterized leadership development as the development of interpersonal skills through key competencies related to social awareness, including empathy and service orientation, and social skills, including bond building and conflict management. Individuals with strong intrapersonal (selfleadership) skills are more innovative and creative (Betta et al., 2010; DiLiello \& Houghton, 2006). The need for both intrapersonal (self-leadership) and interpersonal (the ability to lead others) competency is evident in organizational and professional settings (Day, 2000). Harder \& Narine (2019) indicated that there is a need to include interpersonal leadership competencies in professional development programs. Often, the enhancement of leader interpersonal competencies is incorporated in a leadership development program. For example, in the 
leadership development program emanating from transformational leadership theory, emphasis is placed on developing interpersonal competencies such as effective listening and building trusting relationships (Avolio, 1999; Avolio et al., 2005). Leaders must receive sufficient training to improve intrapersonal (self-leadership) and interpersonal leadership (ability to lead others) competencies. In 2006, Hollenback et al. indicated that the leadership competency model could be used to develop leadership training for intrapersonal and interpersonal competencies development that can help to foster effective leader behavior.

In describing the characteristics of effective leaders, Van Velsor et al. (2010) highlights the need for an individual to lead themselves and lead others, emphasizing the connection between selfleadership competencies and ability to lead others' competencies. The concept of selfleadership originated as a substitute for formal leadership (Manz \& Sims, 1980). Neck and Manz (2010) defined it as "the process of influencing oneself" (p. 4). DiLiello and Houghton (2006) described self-leadership as "a self-influence process that helps individuals develop the selfdirection and self-motivation necessary to perform effectively in the workplace" (p. 326) through the utilization of the following types of strategies:

1. Behavioral-focused strategies are designed to help individuals improve self-awareness, selfgoal setting, self-reward, self-observation, self-punishment, and self-cueing.

2. Natural reward strategies are designed to enhance an individual's competence that helps energize performance-enhancing task behavior (Neck \& Houghton, 2006) and enhance intrinsic motivation (Deci \& Ryan, 1985).

3. Constructive thought pattern strategies are designed to help in creative and positive thinking about oneself and the task that might lead to better performance.

Self-leadership in the workplace can be developed by training employees in self-management, allowing supervisors to focus on other issues and minimize detailed oversight and control. Studies related to the role of interpersonal competencies were conducted in the early to mid1900s and showed that communication and social skills were important predictors of leadership and effectiveness (Bass, 1990; Stogdill, 1974). The theoretical foundation for interpersonal competency development is grounded in the well-known distinction between task-oriented leader behaviors and relationship-oriented behaviors (Likert, 1961; Stogdill \& Coons, 1957). In 1953, Fleishman emphasized the importance of enhancing relationship-oriented aspects of leader behavior, and this approach was adopted and led to programs aimed at developing interpersonal leadership skills. Mumford et al. (2007) defined four categories of leadership competencies among employees: cognitive, interpersonal, business, and strategic skills. Mumford et al. (2007) wrote that interpersonal skills were the most important at all organizational levels.

More recent leadership theories also recognize the importance of interpersonal competency development in effective leadership, particularly the Leader-Member Exchange (LMX)(Graen \& Uhl-Bien, 1995; Uhl-Bien, 2003) and the Transformational Leadership Theory (Bass, 1985; Bass \& Riggio, 2006). LMX plays an important role in defining leadership as being more than leader 
behavior. LMX focuses on the relationship between the leader and follower dyad (Graen \& UhlBien, 1995). This dyadic interaction explains a higher (trustful and respectful) or lower quality of relationship with the followers (Gerstner \& Day, 1997). LMX theory is limited regarding the exploration of the social context in self-leadership and views it as the relationship between leader and follower. Ineffective leaders do not achieve desired outcomes (Kellerman, 2004; Kelloway et al., 2005). Bass (1990) presented four characteristics of transformational leaders: idealized influence, inspirational motivation, intellectual stimulation, and individualized consideration. Bass's transformational leadership model explains that the leader's style positively affects employee motivation, morale, and performance through the following leadership strategies: (1) connecting the follower's sense of identity to the collective identity of the organization; (2) being a role model and inspiring the followers; (3) challenging followers to take greater ownership for their work performance, and understanding followers' strengths and weaknesses to align employees with tasks that enhance their performance. Transformational leaders have been shown to positively affect individual and organizational outcomes, employee satisfaction with leadership, and concern about employees' well-being (Kelloway et al., 2006).

Evans et al. (2015) explained that leadership is a dynamic process, and effective leadership is defined partly by the views of followers (Evans et al., 2015). Therefore, the assessment of interpersonal competencies is one of the most significant factors in managing successful organizations (Gaur, 2019). The authors emphasized that from an organizational and anthropological point of view, "people have a basic instinct to socialize and interact, and they have a need to share their social self with others, in various surroundings such as work, family, or society in general ... Healthy and non-healthy surroundings in the workplace based on interpersonal relationships, can affect the perception of the workplace itself" (p. 2021). Hayes (2002) defined interpersonal competency as an individual ability to understand and manage the dynamic of social interaction. The hierarchical model of interpersonal competency offers the following micro-skills that incorporate the ability of an individual to accept, follow, be an empathetic listener, reflect, communicate, help, give feedback, and negotiate.

Fullan (2001) wrote that the quality of leadership is sometimes judged by the leadership produced in others. A true leader should be able to step back from his leadership role and delegate, help a group to achieve its' goals, and assist others in satisfying their needs while also mediating, initiating organizational actions, and maintaining group functionality (Gibson et al., 2002). The leader represents and personifies the values, motives, and aspirations of the group. Hughes (2007) argued that there are several important factors that make for effective leadership across contexts. Among those factors are the following: good communication, ethical behavior, and strategic thinking. The authors noted that the leaders' communication skills are essential because the leader must be able to receive and transmit information clearly, concisely, and effectively and provide constructive feedback.

Prior to 1990, farm leadership and labor management research in the agriculture sector was limited (Howard and McEwan, 1989). Previous research shows that farm managers play an important role in influencing agricultural safety-related attitudes and actions in the workplace. For example, Mugera and Bitsch (2005) studied labor management practices of dairy farmers 
and determined that human resource development is the source of sustained competitive advantage for dairy farms.

There is limited research on the integration and interaction of farmers' intrapersonal (selfleadership) competencies and interpersonal (ability to lead others) competencies and farmers' quality of life. However, the relationships between specific personality traits (ex. optimism, selfesteem, and self-efficacy) and self-leadership are well studied (Chemers et al., 2000; Khoshhal \& Guraya, 2016; Matzler et al., 2015). Similarly, the relationships between specific personality traits, including those referenced above, and health-related quality of life are examined and described in a systematic review conducted by Huang et al. (2017). As a correlate of overall quality of life (Karimi \& Brazier, 2016), health-related quality of life and its relationship with personality traits provides insight into the relationship between leadership and overall quality of life. Several studies (Friedman et al., 2006; Ong et al., 2006; Sears et al., 2004) found a positive correlation between an individual's perceived level of optimism and quality of life. Individuals who perceived themselves to have greater self-efficacy and higher self-esteem reported higher perceived quality of life (Arnold et al., 2006; Bartoces et al., 2009; Han et al., 2003; Middleton et al., 2007). A study conducted by Yun et al. (2014) integrated personality traits into self-leadership competencies. The relationship between the ability to lead others' competencies and quality of life is examined in a workplace context in the form of quality of work-life among employees. Studies have shown that specific interpersonal leadership competencies/behaviors (ex. inspiration, considerate, strong values) are associated with higher perceived quality of work-life among employees and subordinates within an organization (Corrigan et al., 2000; Suratno et al., 2018).

Lee et al. (2011) mentioned that contacts with family, participation in social groups, have been found to improve people's level of social support, fulfillment of their own relationships, making sense of life, self-esteem, commitment to communities, and psychological and physical wellbeing or quality of life. Shye (2010) wrote:

The individual is regarded in these subsystems as an integral part of a community, and his or her functioning there depends on interpersonal and value interactions and commitments. For example, effective functioning in the social-integrative mode implies interpersonal symmetry; and effective functioning in the social-conservative mode presumes a system of shared norms. Thus, SQOL acknowledges, somewhat in the spirit of Sokolowski's (1996) microsocial model, that one's self-interest-one's quality of life by virtue of one's being enmeshed in a social and cultural network, is intrinsically bound with that of others. (p. 199)

Kleih and Kubler (2014) reported a positive effect of communication competency on an individual's quality of life. They posit that the feeling of autonomy together with the fulfillment of the need for competence might have further positive effects on an individual's quality of life, although the latter relation awaits confirmation.

Based on the outlined theoretical and conceptual framework, we developed our conceptual model, which focused on examining the relationship between farmers' self-leadership 
competencies, ability to lead others' competencies, and farmers' perceived quality of life. In this study, farmers' self-leadership is defined as an individual's intrapersonal leadership competencies development, and farmers' ability to lead others is defined as an individual's interpersonal competencies development, farmers' perceived quality of life is defined as the farmer's conscious cognitive judgment of satisfaction with farm work, family life, and overall health.

\section{Purpose}

The purpose of this study was to explore the relationship between farmers' quality of life, farmers' self-leadership, and the ability to lead others' competencies. Two research objectives guided this study: 1 . Describe farmers' self-leadership and ability to lead others' competencies and farmers' quality of life. 2. Explain the relationship between farmers' quality of life and farmers' self-leadership and ability to lead others' competencies.

\section{Methods}

This research used a survey method in a descriptive correlational study. The study was approved by the university's Behavioral and Social Sciences Review Board. The target for this study was self-identified farmers in Pennsylvania. We utilized the open web page questionnaire method to collect data from Pennsylvania farmers and explore their perceptions of their quality of life and their self-leadership and ability to lead others' competencies. We utilized the unrestricted, self-selected surveys approach (Fricker, 2008), which is a form of convenience sampling. As such, the results cannot be generalized to a larger population (State farmers, $N$ ). "Unrestricted self-selected surveys are surveys that are open to the public for anyone to participate in. They may simply be posted on a website so that anyone browsing through voluntarily may choose to take the survey, or they may be promoted via website banners... Regardless of how they are promoted (or not), the key characteristics of these types of surveys are that there are no restrictions on who can participate, and it is up to the individual to choose to participate (opt-in)." (Fricker, 2008 p. 205). Also, we used the chain-referral sampling approach. According to Penrod et al. (2003), "chain-referral sampling is defined quite similarly to snowball sampling, it relies on a series of participant referrals to others who have experienced the phenomenon of interest" p.102). We asked other agriculture-related organizations in the state to provide referrals to recruit farmers required for this study. Our survey link was available on multiple agriculture-related organizations' websites. Respondents were recruited through the Pennsylvania Extension website, a one-page press release was posted in a state-level online daily farming newspaper, and webpages of counties Farm Bureau, and Facebook pages. We collected data from September 13 to November 17, 2019. After removing responses with missing data, the final data set included responses from 59 farmers ( $n$ =59).

We developed the Farmer's Self-Leadership Competencies scale and Farmer's Ability to Lead Others' Competencies scale using existing literature related to intrapersonal and interpersonal 
leadership competencies (Benge et al., 2011; Bruce \& Anderson, 2012; Conklin et al., 2002; Cooper \& Graham, 2001; Day, 2000; Day \& Dragoni, 2015; Goleman, 2004; Haynes, 2000; Stedman \& Rudd, 2006). Farmers' Self-Leadership Competencies and Farmers' Ability to Lead Others' Competencies scales of the instrument were measured using a five-point Likert scale ranging from 1 (strongly disagree), 2 (disagree), 3 (neither agree nor disagree), 4 (agree), and 5 (strongly agree). Examples of items of the Farmers' Self-Leadership Competencies scale are: "I easily prioritize tasks during my busy season in the farm," I would say I am self-confident, "I have a clear set of values that I apply in my farm business." Examples of items of the Farmers' Ability to Lead Others' Competencies scale are: "I have effective oral communication skills," "I easily work with my farm employees to solve problems," "I delegate tasks effectively to my farm employees." We used Windon et al. (2016) the Farmers' Quality of Life scale to measure farmers' perceptions about their quality of life. The scale was measured using a five-point Likert scale ranging from 1 (very dissatisfied), 2 (somewhat dissatisfied), 3 (neither satisfied nor dissatisfied), 4 (somewhat satisfied), and 5 (very satisfied). Examples of items of the Farmers' Quality of Life scale are: "How satisfied are you with your overall health "?" "How satisfied are you with managing both farm work and family life." A panel of seven Extension educators, Extension administrators, academic faculty members with expertise in survey methodology, farmers, and a graduate student in Extension education reviewed the instrument for face and content validity. The panel of experts determined that the instrument is sufficiently valid. A pilot test was conducted to determine the reliability of the created instrument. The pilot study was conducted in August 2019 during a three-day event, where 40 farmers participated in a paper-pencil survey, with 40 participants filling out the pilot survey. The Cronbach's alpha for the farmers' self-leadership competencies scale was .74, farmers' ability to lead others' competencies scale was .85, and farmers' quality of life scale was .87, which indicated acceptable internal consistency (Cronbach, 1951).

Early and late responses were compared to evaluate non-response errors (Miller \& Smith, 1983). The first twenty-five respondents were assigned as an early phase respondent group, and the last twenty-five respondents were identified as a late phase respondent group. The early and late phases of responders were determined based on the day and time their questionnaire was submitted. $T$-test results indicated that there was no non-response bias (Lindner et al., 2001; Miller \& Smith, 1983), and it revealed that data collected from farmers were representative of the entire study population (see Table 1.)

Caution is advised in interpreting the study findings since the participants of the study are not a random sample. The findings of this study will only apply to those who participated, and as such, cannot be generalized to the entire population of Pennsylvania farmers. 
Table 1

Independent Samples t-test for Equality of Means on Scale Scores of Construct between Early and Late Respondents

\begin{tabular}{|c|c|c|c|c|c|c|}
\hline \multirow[t]{3}{*}{ Scale } & \multicolumn{6}{|c|}{ Respondents } \\
\hline & \multicolumn{2}{|c|}{ Early $(n=25)$} & \multicolumn{4}{|c|}{ Late $(n=25)$} \\
\hline & $M$ & $S D$ & $M$ & $S D$ & $t$ & $p$ \\
\hline $\begin{array}{l}\text { Farmers' self-leadership } \\
\text { competencies }\end{array}$ & 3.89 & .43 & 3.95 & .54 & .46 & .65 \\
\hline $\begin{array}{l}\text { Farmers' ability to lead others' } \\
\text { competencies }\end{array}$ & 3.97 & .41 & 4.02 & .50 & .42 & .68 \\
\hline Farmers' quality of life & 3.39 & .62 & 3.54 & .74 & .74 & .46 \\
\hline
\end{tabular}

Note. $\mathrm{p}<.05$

We used SPSS ${ }^{\circledR}$ version 25 to conduct data analysis for our study. Independent variables and the dependent variables were treated as interval data. A descriptive statistic was utilized to describe the first research objective. A multiple linear regression analysis was conducted to answer the second research objective - determine the relationship between overall farmers' quality of life (dependent variable) and independent variables, such as farmers' self-leadership and ability to lead others' competencies. We used Davis (1971) conventions to describe the magnitude of the relationships between independent and dependent variables.

\section{Findings}

The first research objective was to describe farmers' perceptions of their self-leadership competencies, ability to lead others' competencies, and farmers' quality of life. The overall mean score for farmers' self-leadership competencies was $3.93(S D=.48, n=59)$. Results are shown in Table 2. Lower scores indicate greater needs of self-leadership competencies content areas, and higher scores indicate greater proficiency in the area. Farmers indicated greater needs in the following self-leadership competencies: balancing personal and professional life during the busy season on the farm, handle stress, quickly make decisions, and easily prioritize tasks during my busy season on the farm. Farmers were proficient in applying set values in the workplace, working independently on the farm, they felt self-confident and could achieve farm business goals. 


\section{Table 2}

Farmers' Self-leadership Competencies

\begin{tabular}{llll}
\hline \multicolumn{1}{c}{ Items } & $\boldsymbol{n}$ & $\boldsymbol{M}$ & \multicolumn{1}{l}{$\boldsymbol{S D}$} \\
\hline $\begin{array}{l}\text { I balance my personal and professional life during the busy season } \\
\text { on the farm }\end{array}$ & 58 & 3.19 & 1.02 \\
I handle farm stress effectively & 57 & 3.39 & .88 \\
I quickly make decisions & 57 & 3.72 & .98 \\
I easily prioritize tasks during my busy season on the farm & 57 & 3.82 & .83 \\
I achieve my farm business goals. & 57 & 4.02 & .64 \\
I would say I am self-confident. & 58 & 4.17 & .88 \\
I have a clear set of values that I apply in my farm business & 58 & 4.60 & .59 \\
I easily work independently on the farm. & 57 & 4.60 & .62 \\
Overall farmers' self-leadership competencies & 59 & 3.93 & .482 \\
\hline
\end{tabular}

The overall mean score for the farmers' ability to lead others' competency was $3.96(S D=.50, n$ =59). Results are shown in Table 3. Lower scores indicate greater needs in terms of ability to lead others' competencies content areas, and higher scores indicate greater proficiency in the area. Farmers indicated greater needs related to effective engagement in difficult conversations with farm employees and effective delegation of tasks to farm employees, managing people at the farm, delegate tasks effectively to farm employees, and effective oral communication skills. Farmers were comfortable networking with others within the farmers' community and solving complex problems on the farm.

\section{Table 3}

Farmers' Ability to Lead Others' Competencies

\begin{tabular}{llll}
\hline \multicolumn{1}{c}{ Items } & $\boldsymbol{n}$ & $\boldsymbol{M}$ & \multicolumn{1}{c}{$\boldsymbol{S D}$} \\
\hline $\begin{array}{l}\text { I effectively engage in difficult conversations with my farm } \\
\text { employees }\end{array}$ & 57 & 3.70 & .80 \\
I am good at managing people at my farm. & 57 & 3.75 & .89 \\
I delegate tasks effectively to my farm employees & 55 & 3.78 & .90 \\
I am effective at motivating my farm employees. & 46 & 3.83 & .71 \\
I have effective oral communication skills & 57 & 3.96 & .94 \\
I am a mentor to my farm employees. & 46 & 4.00 & .79 \\
I am an effective listener & 57 & 4.05 & .79 \\
I have effective written communication skills. & 57 & 4.07 & .90 \\
I easily work with my farm employees to solve problems. & 49 & 4.08 & .73 \\
I solve complex problems on the farm. & 58 & 4.16 & .64 \\
I am comfortable networking with others from my farmers' & 58 & 4.17 & .75 \\
$\quad$ community & & & \\
Overall farmers' ability to lead others' competencies & 58 & 3.96 & .50 \\
\hline
\end{tabular}


The overall mean score for the 'farmers' quality of life was $3.49(S D=.69, n=59)$. Results are shown in Table 4. During the busiest season of the year, farmers reported that they were satisfied with their farm work and overall health. However, farmers were less satisfied with their hours of sleep, vacation time, and managing farm work and family life, social activities, emotional support from others, and work hours during their busy season.

\section{Table 4}

Farmers' Quality of Life

\begin{tabular}{llll}
\hline \multicolumn{1}{c}{ Items } & $\boldsymbol{n}$ & $\boldsymbol{M}$ & \multicolumn{1}{c}{$\boldsymbol{S D}$} \\
\hline How satisfied are you with your hours of sleep? & 56 & 3.16 & 1.01 \\
How satisfied are you with your received time for vacation or years off? & 55 & 3.18 & 1.22 \\
How satisfied are you with managing both farm work and family life? & 54 & 3.19 & 1.07 \\
How satisfied are you with your social activities? & 58 & 3.22 & 1.01 \\
How satisfied are you with your emotional support from others? & 57 & 3.39 & 1.08 \\
How satisfied are you with your work hours? & 54 & 3.61 & .78 \\
How satisfied are you with your overall health? & 58 & 3.79 & .91 \\
How satisfied are you with your farm work? & 54 & 3.81 & .70 \\
Overall quality of life & 58 & 3.49 & .69 \\
\hline
\end{tabular}

Note. Questions were asked in relation to the busiest farm season for the year studied.

The second research objective was to explain the relationship between farmers' perceptions of their quality of life and self-leadership competencies and ability to lead others' competencies. Application of the Pearson correlation coefficient showed a significant positive association between self-leadership competencies and ability to lead others' competencies $(r=.55, p=$ $.001)$, farmers' self-leadership competencies and quality of life $(r=.63, p=.001)$, and ability to lead others' competencies and quality of life $(r=.24, p=.013)$.

A multiple linear regression analysis was conducted to determine the relationship between overall farmers' quality of life (dependent variable) and independent variables such as farmers' self-leadership competencies and ability to lead others' competencies. The results indicated that a significant proportion of the total variance in overall farmers' quality of life was predicted by farmers' self-leadership competencies and ability to lead others' competencies $F(2,54)=$ $20.60, p<.001$. Multiple $R^{2}$ indicated that approximately $43 \%$ of the variation in overall farmers' quality of life could be explained by farmers' self-leadership competencies and ability to lead others' competencies (see Table 5). 


\section{Table 5}

Multiple Regression Analysis Between Farmers' Quality of Life, Farmer's self-Leadership and Ability to Lead Others' Competencies Domains

\begin{tabular}{|c|c|c|c|c|c|c|c|c|c|}
\hline \multicolumn{10}{|c|}{ Model Fit } \\
\hline & \multirow[b]{2}{*}{$R$} & \multicolumn{8}{|c|}{ Change Statistics } \\
\hline & & $R^{2}$ & Adj. $R$ & S.E. & $R^{2}$ & $F$ & $d f 1$ & $d f 2$ & $p$ \\
\hline 1 & .66 & .43 & .41 & .53 & .43 & 20.60 & 2 & 54 & .000 \\
\hline
\end{tabular}

Note. $p<.05$

Analysis of variance in overall farmers' quality of life is presented in Table 6.

Table 6

Analysis of Variance in Support for Farmers' Quality of Life

\begin{tabular}{llllll}
\hline Model & Sum of Squared & $d f$ & Mean Square & $F$ & $p$ \\
\hline Regression & 11.65 & 2 & 5.82 & 20.60 & .000 \\
Residual & 15.27 & 54 & .28 & & \\
Total & 26.91 & 56 & & & \\
\hline
\end{tabular}

Note. $p<.05$

Within the final model, both factors were significant predictors of farmers quality of life namely, farmers' self-leadership competencies $(B=.70 ; p$-value $<.001)$ and ability to lead others' competencies $(B=.34 ; p$-value $=.047)$. Multiple relations' coefficients are presented in Table 7.

\section{Table 7}

Multiple Relations Coefficients

\begin{tabular}{lllll}
\hline Model & $B$ & SER & 6 & $p$-value \\
\hline Constant & -.62 & .65 & & .347 \\
$\begin{array}{l}\text { Farmers' self-leadership } \\
\quad \text { competencies }\end{array}$ & .70 & .18 & .49 & .000 \\
Ability to lead others' competencies & .34 & .17 & .25 & .047 \\
\hline
\end{tabular}

Note. $p<.05$

\section{Conclusions, Discussion, and Recommendations}

This study makes a unique contribution to the research in the field of individual's quality of life in relationship with intrapersonal and interpersonal leadership competencies. The results of this study indicated that farmers generally have a high perception of their self-leadership and ability to lead others' competencies. Among those farmers' competencies was working independently, solving complex problems, achieving their planned goals, and effectively 
managing employees. Previous studies showed that certain self-leadership competencies moderate the effects of work stressors, and those with high self-leadership competencies were more effective in managing their stress (Thompson \& Gomez, 2014). While farmer selfleadership and ability to lead others' competencies were high, the study results indicated specific areas of greater need related to personal work-life balance. This need for improved work-life balance is consistent with previous studies that reported an individual's ability to balance work and personal family life is a significant factor related to their perceived quality of life (Greenhaus et al., 2003). Another reported area of need among farmers was the ability to have difficult conversations with farm employees. The result of this study supports previous research that emphasizes the leaders' challenge in having difficult or awkward conversations with their employees (Angelo, 2019; Bradley \& Campbell, 2016; Overton \& Lowry, 2013).

We found a significant relationship between the perceived quality of life and farmers' selfleadership competencies and the ability to lead others' competencies. The study results suggest that greater leadership skills (self-leadership and ability to lead others' competencies) correspond to greater perceived quality of life. The results of this study are consistent with previous studies (Herrera et al., 2018; Kong et al., 2019) that reported the farmers' organizational management, interpersonal competencies, self-leadership competencies relate to farmers' quality of life. The findings of this study also identify potential areas of need in farmers' self-leadership and ability to lead others' competencies development that relates to perceived quality of life.

The study results suggest targeted leadership programming is necessary to address identified areas of need among farmers. Currently, the Pennsylvania Extension service provides a general leadership education, where interpersonal interactions and conflict resolution are minor components of the curriculum, with the work-life balance not explicitly addressed. This, however, is not sufficient to address the observed farmer leadership needs in the study; thus, consideration should be given to developing specific farmer leadership development programs in the following two areas. First, human resource and Extension practitioners should develop an education program for farmers that will address work-life balance and work stress. It is known that work-life imbalance, especially excessive time dedicated to work, negatively impacts the quality of life (Greenhaus et al., 2003). Work stress is considered a major factor that negatively impacts work-life balance. As mentioned earlier, farming is a high-stress occupation, with many stressors, including a high workload, large time commitment, high levels of uncertainty, and business and financial challenges (Parry et al., 2005). Extension programming should seek to address the common causes of farmer stress and provide specific strategies to improve farmers' ability to manage workload and time with family. Also, Extension programming for farmers should focus on the issue of having difficult conversations with farm employees. As mentioned earlier, this is a challenge for many leaders in organizational settings. Programming should provide strategies for approaching the situation, having the conversation, and moving forward afterward. A potential program could use the strategies outlined in Bradley and Campbell (2016), who provide a framework for managing the process of having difficult conversations in a work environment. It is important that this theoretical component is paired 
with a practical component that would allow participants to apply learned strategies and develop their communication skills in a controlled setting.

It is important to note that based on the nature of the study, it is difficult to assess the applicability of the results outside of farmers in Pennsylvania or the specific programmatic needs of different state Extension services. However, the study results provide important insight to Extension and human resources practitioners by providing guidance toward identifying specific farmer needs and developing relevant Extension programs for farmers in their state. The results of this study build a greater understanding of the relationship between quality of life and self-leadership and the ability to lead others' competencies by expanding the scope of research to a non-traditional, unique context. Finally, this study provides a basis from which future research can be done to examine further the relationship in the context of other agricultural, organizational, and community leaders.

Future studies may want to include a qualitative component to examine the perceived quality of life among farmers. Further research should explore the relationship between farmers' selfleadership and the ability to lead others' competencies and quality of life based on farmers' demographics. It would also be beneficial to conduct a longitudinal study to understand better the long-term effects of perceived leadership competency on farmers' quality of life.

\section{References}

Angelo, E. (2019). Managing interpersonal conflict: Steps for success. Nursing Management, 50(6), 22-28. https://doi.org/10.1097/01.NUMA.0000558479.54449.ed

Arnold, R., Ranchor, A. V., Koeter, G. H., de Jongste, M. J. L., Wempe, J. B., ten Hacken, N. H. T., Otten, V., \& Sanderman, R. (2006). Changes in personal control as a predictor of quality of life after pulmonary rehabilitation. Patient Education and Counseling, 61(1), 99-108. https://doi.org/10.1016/j.pec.2005.02.015

Avolio, B. J. (1999). Full leadership development: Building the vital forces in organizations. Sage

Avolio, B. J., Chan, A., Chan, N., Galanhxi-Janaqi, H., Gitlitz, J., Hannah, S., \& Zhu, W. (2005). 100-year review of leadership intervention research: Briefings report 2004-01, Gallup Leadership Institute. Leadership Review, 5, 7-13.

Bartoces, M. G., Severson, R. K., Rusin, B. A., Schwartz, K. L., Ruterbusch, J. J., \& Neale, A. V. (2009). Quality of life and self-esteem of long-term survivors of invasive and noninvasive cervical cancer. Journal of 'Women's Health, 18(5), 655-661. https://doi.org/10.1089/jwh.2008.0959

Bass, B. (1985). Leadership and performance beyond expectations. Free Press. 
Bass, B. (1990). From transactional to transformational leadership: Learning to share the vision. Organizational Dynamics, 18, 19-31. https://doi.org/10.1016/0090-2616(90)90061-S

Bass, B. M., \& Riggio, R. E. (2006). Transformational leadership (2nd ed.). Lawrence Erlbaum Associates Publishers.

Benge, M., Harder, A., \& Carter, H. (2011). Necessary pre-entry competencies as perceived by Florida Extension agents. Journal of Extension, 49(5). https://www.joe.org/joe/2011october/a2.php

Betta, M., Jones, R., \& Latham, J. (2010). Entrepreneurship and the innovative self: A Schumpeterian reflection. International Journal of Entrepreneurial Behavior \& Research, 16(3), 229-244. https://doi.org/10.1108/13552551011042807

Bogue, P., \& Phelan, J. (2005). Exploring the quality of life of farm families in Ireland: Implications for Extension. Journal of International Agricultural and Extension Education, 12(3), 79-90. https://doi.org/10.5191/jiaee.2005.12307

Bradley, G. L., \& Campbell, A. C. (2016). Managing difficult workplace conversations: Goals, strategies, and outcomes. International Journal of Business Communication, 53(4), 443464. https://doi.org/10.1177/2329488414525468

Bruce, J. A., \& Anderson, J. (2012). Perceptions of the training needs of the newest members of the Extension family. Journal of Extension, 50(6). https://www.joe.org/joe/2012december/pdf/JOE_v50 6rb5.pdf

Campbell, A., Converse, P. E., \& Rodger, W. L. (1976). The quality of American life: Perceptions, evaluations, and satisfactions. Russell Sage Foundation.

Chemers, M. M., Watson, C. B., \& May, S. T. (2000). Dispositional affect and leadership effectiveness: A comparison of self-esteem, optimism, and efficacy. Personality and Social Psychology Bulletin, 26(3), 267-277. https://doi.org/10.1177/0146167200265001

Clark, A. E. (2010). Work, jobs, and well-being across the millennium. In E. Diener, J. F. Helliwell, \& D. Kahneman (Eds.), International differences in well-being (pp. 436-468). Oxford University Press. https://doi.org/10.1093/acprof:oso/9780199732739.003.0014

Conklin, N. L., Hook, L. L., Kelbaugh, B. J., \& Nieto, R. D. (2002). Examining a professional development system: A comprehensive needs assessment approach. Journal of Extension, 40(5), 1-9. https://www.joe.org/joe/2002october/a1.php

Cooper, A. W., \& Graham, D. L. (2001). Competencies needed to be successful county agents and county supervisors. Journal of Extension, 39(1), 1-11. https://www.joe.org/joe/2001february/rb3.php 
Corrigan, P. W., Lickey, S. E., Campion, J., \& Rashid, F. (2000). Mental health team leadership and "consumers' satisfaction and quality of life. Psychiatric Services, 51(6), 781-785. https://doi.org/10.1176/appi.ps.51.6.781

Coughenour, C. M., \& Swanson, L. E. (1988). Rewards, values, and satisfaction with farm work. Rural Sociology, 53(4), 442-459.

Cronbach, L. J. (1951). Coefficient alpha and the internal structure of tests. Psychometrika, 16(3), 297-334. https://doi.org/10.1007/bf02310555

Davis, J. A. (1971). Elementary survey analysis. Prentice-Hall.

Day, D. V. (2000). Leadership development: A review in context. The Leadership Quarterly, 11(4), 581-613. https://doi.org/10.1016/S1048-9843(00)00061-8

Day, D. V., \& Dragoni, L. (2015). Leadership development: An outcome-oriented review based on time and levels of analyses. Annual Review of Organizational Psychology and Organizational Behavior, 2, 133-156. https://doi.org/10.1146/annurev-orgpsych$\underline{\text { 032414-111328 }}$

Deci, E. L., \& Ryan, R. M. (1985). Intrinsic motivation and self-determination in human behavior. Plenum.

DiLiello, T. C., \& Houghton, J. D. (2006). Maximizing organizational leadership capacity for the future: Toward a model of self-leadership, innovation and creativity. Journal of Managerial Psychology, 21(4), 319-337. https://doi.org/10.1108/02683940610663114

Dillman, D. A., \& Tremblay Jr, K. R. (1977). The quality of life in rural America. The Annals of the American Academy of Political and Social Science, 429(1), 115-129. https://doi.org/10.1177\%2F000271627742900111

Evans, L. S., Hicks, C. C., Cohen, P. J., Case, P., Prideaux, M., \& Mills, D. J. (2015). Understanding leadership in the environmental sciences. Ecology and Society, 20(1). https://doi.org/10.5751/es-07268-200150

Fleishman, E. A. (1953). Leadership climate, human relations training, and supervisory behavior. Personnel Psychology, 6(2), 205-222. https://doi.org/10.1111/j.17446570.1953.tb01040.x

Friedman, L. C., Kalidis, M., Elledge, R., Chang, J., Romero, C., Husain, I., Dulay, M. F., \& Liscum, K. R. (2006). Optimism, social support and psychosocial functioning among women with breast cancer. Psycho-Oncology, 15(7), 595-603. https://doi.org/10.1002/pon.992 
Fricker, R. D. (2008). Sampling methods for web and email surveys. In N. Fielding, M.L. Raymond, \& G. Blank (Ed.), The Sage handbook of online research methods (pp. 195216). Sage Publications. https://methods.sagepub.com/book/the-sage-handbook-ofonline-research-methods/n11.xml

Fullan, M. (2001). Leading in a culture of change. Jossey-Bass.

Gaur, D. (2019). Self-leadership and interpersonal competences of future aspiring professionals in the Arab Middle East: Reference to FIRO-B. Management Science Letters, 9(2019), 2021-2028.

Gerstner, C. R., \& Day, D. V. (1997). Meta-analytic review of leader-member exchange theory: Correlates and construct issues. Journal of Applied Psychology, 82(6), 827-744. https://doi.org/10.1037/0021-9010.82.6.827

Gibson, J. L., Ivancevich, J. M., Donnelly, J. H., \& Konopaske, R. (2002). Organizations behavior, structure, processes (12th ed.). McGraw-Hill.

Goleman, D. (2004). What makes a leader? Harvard Business Review, 82(1), 82-91. https://hbr.org/2004/01/what-makes-a-leader

Graen, G. B., \& Uhl-Bien, M. (1995). Relationship-based approach to leadership: Development of leader-member-exchange (LMX) theory of leadership over 25 years: Applying a multilevel multi-do-main perspective. Leadership Quarterly, 6(2), 219-247. https://doi.org/10.1016/1048-9843(95)90036-5

Greenhaus, J. H., Collins, K. M., \& Shaw, J. D. (2003). The relation between work-family balance and quality of life. Journal of Vocational Behavior, 63(3), 510-531. https://doi.org/10.1016/S0001-8791(02)00042-8

Han, K. S., Lee, P. S., Lee, S. J., \& Park, E. S. (2004). Factors influencing quality of life in people with chronic illness in Korea. Journal of Nursing Scholarship, 35(2), 139-144. https://doi.org/10.1111/j.1547-5069.2003.00139.x

Harder, A., \& Narine, L. K. (2019). Interpersonal leadership competencies of extension agents in Florida. Journal of Agricultural Education, 60(1), 224-233. https://doi.org/10.5032/jae.2019.01224

Hagevoort, G. R., Douphrate, D. I., \& Reynolds, S. J. (2013). A review of health and safety leadership and managerial practices on modern dairy farms. Journal of Agromedicine, 18(3), 265-273. https://doi.org/10.1080/1059924X.2013.796905

Hayes, J. (2002). The theory and practice of change management. Palgrave Macmillan. 
Haynes, B. R. (2000). Management skills of county Extension administrators: Are they sufficient to do the job? Journal of Extension, 38(2). https://www.joe.org/joe/2000april/rb2.php

Herrera, B., Gerster-Bentaya, M., \& Knierim, A. (2018, July 28 - August 2). Farm-level factors influencing farmers satisfaction with their work [Paper Presentation]. 30th International Conference of Agricultural Economists, Vancouver, Canada. https://ageconsearch.umn.edu/record/277024/files/641.pdf.

Hofmann, D., \& Morgeson, F. (1999). Safety-related behavior as a social exchange: The role of perceived organizational support and leader-member exchange. Journal of Applied Psychology, 84, 286-296. https://psycnet.apa.org/doi/10.1037/0021-9010.84.2.286

Hollenback, G. P., McCall, M. W., \& Silzer, R. F. (2006). Leadership competency models. The Leadership Quarterly, 17(4), 398-413. https://doi.org/10.1016/j.leaqua.2006.04.003

Howard, W. H., \& McEwan, K. A. (1989). Human resource management: A review with applications to agriculture. Canadian Journal of Agricultural Economics, 37(4), 733. https://doi.org/10.1111/j.1744-7976.1989.tb00790.x

Huang, H. Y., Tsai, W. C., Chou, W. Y., Hung, Y. C., Liu, L. C., Huang, K. F., Wang, W. C., Leung, K. W., Hsieh, R. K., \& Kung, P. T. (2017). Quality of life of breast and cervical cancer survivors. BMC women's health, 17(1), Article 30. https://doi.org/10.1186/s12905-017$\underline{0387-x}$

Hughes O. E. (2007). Leadership in a managerial context. In: R. Koch \& J. Dixon (Eds.), Public Governance and Leadership. 319-340. Deutscher Universitäts-Verlag. https://doi.org/10.1007/978-3-8350-9100-9 15

Judge, T., \& Bono, J. (2000). Five-factor model of personality and transformational leadership. Journal of Applied Psychology, 85(5), 751-765. https://psycnet.apa.org/record/2000$\underline{\text { 03966-007 }}$

Karimi, M., \& Brazier, J. (2016). Health, health-related quality of life, and quality of life: What is the difference? PharmacoEconomics, 34(7), 645-649. https://doi.org/10.1007/s40273$\underline{016-0389-9}$

Kellerman, B. (2004). Bad leadership. Harvard Business School Press

Kelloway E., Mullen, J., \& Francis, L. (2006). Divergent effects of transformational and passive leadership on employee safety. Journal of Occupational Health Psychology, 11(1), 7686. https://www.proquest.com/docview/614499898?pqorigsite $=360$ link \&accountid $=13158$ 
Kelloway, E., Sivanathan, N., Francis, L., \& Barling, J. (2005). Poor leadership. In J. Barling, E. Kelloway, \& M. Frone (Eds.), Handbook of workplace stress (pp. 89-112). Sage.

Khoshhal, K. I., \& Guraya, S. Y. (2016). Leaders produce leaders and managers produce followers. A systematic review of the desired competencies and standard settings for physicians' leadership. Saudi Medical Journal, 37(10), 1061-1067. https://doi.org/10.15537/smj.2016.10.15620

Kleih, S. C., \& Kübler, A. (2014). Psychological perspectives: Quality of life and motivation. In Grubler, G., \& Hildt, E. (Eds.) Brain-computer-interfaces in their ethical, social and cultural contexts (pp. 77-84). Springer, Dordrecht. https://link.springer.com/chapter/10.1007/978-94-017-8996-7 6

Kong, F. Z., Zhao, L., Zhang, X. B., Tsai, C. H., \& Lin, D. D. (2019). "Farmers' work-life quality and entrepreneurship will in China. Frontiers in Psychology, 10, Article 787. https://doi.org/10.3389/fpsyg.2019.00787

Lee, P. S. N., Leung, L., Lo, V., Xiong, C., \& Wu, T. (2011). Internet communication versus face-toface interaction in quality of life. Social Indicators Research, 100, 375-389. https://doi.org/10.1007/s11205-010-9618-3

Likert, R. (1961). New patterns of management. McGraw-Hill.

Lindner, J. R., Murphy, T. H., \& Briers, G. E. (2001). Handling non-response in social science research. Journal of Agricultural Education, 42(4), 43-53. https://doi.org/10.5032/jae.2001.04043

Macdonald, J. M. (2020). Tracking the consolidation of US agriculture. Applied Economic Perspectives and Policy, 42(3), 361-379. https://doi.org/10.1002/aepp.13056

McClelland, D. C. (1973). Testing for competence rather than intelligence. American Psychologist, 28(1), 1-14. https://www.proquest.com/docview/614349694?accountid=13158\&pq-origsite=360link

Manz, C. C., \& Sims, H. P. (1980). Self-management as a substitute for leadership: A social learning theory perspective. Academy of Management Review, 5(3), 361 -367. https://www.jstor.org/stable/257111?seq=1\#metadata info tab contents

Manz, C. C., \& Sims, H. P. (2001). The new superleadership: Leading others to lead themselves, Berrett-Koehler Publishers.

Matzler, K., Bauer, F. A., \& Mooradian, T. A. (2015). Self-esteem and transformational leadership. Journal of Managerial Psychology, 30(7), 815-831. https://doi.org/10.1108/JMP-01-2013-0030 
Middleton, J., Tran, Y., \& Craig, A. (2007). Relationship between quality of life and self-efficacy in persons with spinal cord injuries. Archives of Physical Medicine and Rehabilitation, 88(12), 1643-1648. https://doi.org/10.1016/i.apmr.2007.09.001

Miller, L. E., \& Smith K. L. (1983). Handling non-response issues. Journal of Extension, 21(5), 45-50. https://archives.joe.org/joe/1983september/83-5-a7.pdf

Meeting Professionals International (MPI). (2012). Meeting and business event competency standards curriculum guide. MBECS.

Molnar, J. J. (1985). Determinants of subjective well-being among farm operators: Characteristics of the individual and the firm. Rural Sociology, 50(2), 141-162.

Mugera, A. W., \& Bitsch, V. (2005). Managing labor on dairy farms: A resource-based perspective with evidence from case studies. International Food and Agribusiness Management Review, 8(3), 79-98.

Mumford, T. V., Campion, M. A., \& Morgeson, F. P. (2007). The leadership skills strataplex: Leadership skill requirements across organizational levels. The Leadership Quarterly, 18(2), 154-166. https://doi.org/10.1016/i.leaqua.2007.01.005

Nanus, B. (1992). Visionary leadership: Creating a compelling sense of direction for your organization. Jossey-Bass.

Neck, C. P., \& Houghton, J. D. (2006). Two decades of self-leadership theory and research: Past developments, present trends, and future possibilities. Journal of Managerial Psychology, 21(4). https://doi.org/10.1108/02683940610663097

Neck, C. P., \& Manz, C. C. (2010). Mastering self-leadership: Empowering yourself for personal excellence (5th ed.). Prentice Hall.

Nitsch, U. U. (1987). A persistent culture: Some reflections on Swedish family farming. In B. Galeski \& E. Wilkening (Eds.), Family farming in Europe and America (pp. 95-115). Westview Press.

Noll, H. H. (2002). Towards a European system of social indicators: Theoretical framework and system architecture. Social Indicators Research, 58(1/3), 47-87. https://doi.org/10.1023/a:1015775631413

Ong, L., Cribbie, R., Harris, L., Dorian, P., Newman, D., Mangat, I., Nolan, R., \& Irvine, J. (2006). Psychological correlates of quality of life in atrial fibrillation. Quality of Life Research, 15, 1323-1333. https://doi.org/10.1007/s11136-006-0029-5 
Overton, A. R., \& Lowry, A. C. (2013). Conflict management: Difficult conversations with difficult people. Clinics in Colon and Rectal Surgery, 26(4), 259-264. https://doi.org/10.1055/s$\underline{0033-1356728}$

Parry, J., Barnes, H., Lindsey, R., \& Taylor, R. (2005). Farmers, farm workers, and work-related stress (Research Report 362). Department for Work and Pensions, Health \& Safety Executive. https://eprints.soton.ac.uk/207675/1/Farmers\%252C farm workers and work related stress.pdf

Paxson, M., Howell, R. E., Michael, J. A., \& Wong, S. K. (1993). Leadership development in Extension. Journal of Extension, 31(1). https://www.joe.org/joe/1993spring/rb2.php

Penrod, J., Preston, D. B., Cain, R. E., \& Starks, M. T. (2003). A discussion of chain referral as a method of sampling hard-to-reach populations. Journal of Transcultural Nursing, 14(2), 100-107. https://doi.org/10.1177\%2F1043659602250614

Pretty, J. (1995). Participatory learning for sustainable agriculture. World Development, 23, 1247-1263. https://doi.org/10.1016/0305-750X(95)00046-F

Rejeski, W. J., \& Mihalko, S. L. (2001). Physical activity and quality of life in older adults. The Journals of Gerontology Series A: Biological Sciences and Medical Sciences, 56(suppl_2), 23-35. https://doi.org/10.1093/gerona/56.suppl 2.23

Sears, S. F., Serber, E. R., Lewis, T. S., Walker, R. L., Conners, N., Lee, J. T., Curtis, A. B., \& Conti, J. B. (2004). Do positive health expectations and optimism relate to quality-of-life outcomes for the patient with an implantable cardioverter defibrillator? Journal of Cardiopulmonary Rehabilitation, 24(5), 324-331. https://doi.org/10.1097/00008483$\underline{200409000-00008}$

Shye, S. (2010). The motivation to volunteer: A systemic quality of life theory. Social Indicators Research, 98(2), 183-200. https://doi.org/10.1007/s11205-009-9545-3

Stedman, N. L., \& Rudd, R. (2006). Leadership styles and volunteer administration competence: Perceptions of 4-H county faculty in the United States. Journal of Extension, 44(1). https://www.joe.org/joe/2006february/rb6.php

Stogdill, R. M. (1974). Handbook of leadership: A survey of theory and research. Free Press.

Stogdill, R. M., \& Coons, A. E. (Eds.). (1957). Leader behavior: Its description and measurement. Ohio State University, Bureau of Business Research. 
Suratno, K., Ariyanti, S., \& Kusrini S, K. (2018). The Relationship between transformational leadership and quality of nursing work life in hospital. International Journal of Caring Sciences, 11(3), 1416-1422. http://www.internationaljournalofcaringsciences.org/docs/9 kalukuSuratno original 1 1 3.pdf

Thompson, J., \& Gomez, R. (2014). The role of self-esteem and self-efficacy in moderating the effect of workplace stress on depression, anxiety and stress. Australasian Journal of Organizational Psychology, 7(e2), 1-14. https://doi.org/10.1017/orp.2014.2

Uhl_Bien, M. (2003). Relationship development as a key ingredient for leadership development. In S. E. Murphy \& R. E. Riggio (Eds.), The future of leadership development (pp. 129-147). Lawrence Erlbaum Associates.

Ulvenblad, P., \& Cederholm Björklund, J. (2018). A leadership development programme for agricultural entrepreneurs in Sweden. The Journal of Agricultural Education and Extension, 24(4), 327-343. https://doi.org/10.1080/1389224x.2018.1473260

United States Department of Agriculture National Agricultural Statistics Service [USDA NASS]. (2017). 2017 Census of Agriculture - United States data: Table 1. Historical highlights: 2017 and earlier census years [Data Set]. https://www.nass.usda.gov

Van Velsor, E., McCauley, C. D., \& Ruderman, M. N. (2010). The Center for Creative Leadership handbook of leadership development (3rd ed.). Jossey-Bass.

Whoqol Group. (1995). The World Health Organization quality of life assessment (WHOQOL): Position paper from the World Health Organization. Social Science \& Medicine, 41(10), 1403-1409. https://doi.org/10.1016/0277-9536(95)00112-K

Windon, S. R., Jepsen, S. D., \& Scheer, S. D. (2016). Examining the quality of life of farmers with disabilities: The Ohio AgrAbility Study. Journal of Agricultural Safety and Health, 22(1), 313. https://doi.org/10.13031/jash.22.10929

World Health Organization. (1997). WHOQOL: Measuring quality of life.https://www.who.int/mental health/media/68.pdf

Young, R. D. (2008). Quality of life indicator systems-Definitions, methodologies, uses, and public policy decision making. [White Paper]. http://www.ipspr.sc.edu/publication/Quality\%20of\%20Life.pdf 
Yun, Y. H., Sim, J. A., Jung, J. Y., Noh, D., Lee, E. S., Kim, Y. W., Oh, J. H., Ro, J. S., Park, S. Y., Park, S. J., Cho, K. H., Chang, Y. J., Bae, Y. M., Kim, S. Y., Jung, K. H., Zo, Z. I., Lim, J., \& Lee, S. N. (2014). The association of self-leadership, health behaviors, and posttraumatic growth with health-related quality of life in patients with cancer. Psycho-Oncology, 23(12), 1423-1430. https://doi.org/10.1002/pon.3582

(C) 2021 by authors. This article is an open access article distributed under the terms and conditions of the Creative Commons Attribution license (http://creativecommons.org/licenses/by/4.0/). 